INVESTIGACIÓN / RESEARCH

\title{
Efficacy of Plectranthus amboinicus (Lour.) Spreng (French oregano) tablets in patients with common cold: a randomized, double-blind, placebo-controlled study
}

\author{
Eficacia de las tabletas de Plectranthus amboinicus (Lour.) Spreng (Oréga- \\ no francés) en pacientes con catarro común: estudio aleatorizado, a doble \\ ciego, controlado con placebo
}

Yolanda A Rodríguez-Cámbara ${ }^{1}$, Daise Jiménez-Rodríguez ${ }^{2}$, Jorge E Rodríguez-Chanfrau ${ }^{2}$, Midalis Gracial-Serrano ${ }^{1}$, Tatiana Festary-Casanovas ${ }^{2}$, Mabel C Luaces-Argüelles ${ }^{1}$, Joaquina Gómez-Peire ${ }^{1}$, Ángela D Tuero-Iglesias ${ }^{3}$, Idrian García-García ${ }^{2}$

\section{ABSTRACT}

Medicinal plants with healing properties could be used to improve medical attendance. Common cold is a very high frequent disease but their treatment is not always available and adequate. Particularly, French oregano had demonstrated expectorant and antitussive properties at non-clinical level. A randomized, double-blind, placebo-controlled clinical trial was carried out to evaluate if French oregano tablets could quickly suppress common cold symptoms in patients with upper respiratory tract infections, being superior to symptomatic treatment. Patients received placebo or oregano (300 or $600 \mathrm{mg}$ ), daily, during 15 days, combined to abundant liquid and antipyretics on the presence of fever or malaise. Each group was formed by 30 patients. The frequency and intensity of cough and the amount of expectoration were assessed weekly. After first week of treatment, cough frequency was significantly lower in those patients treated with $600 \mathrm{mg}$ comparing other groups $(p=0.003)$. Cough disappeared in 20 patients from the highest dose group. At that time, this group had best results concerning reduction in cough intensity $(p=$ $0.046)$ and increase in the amount of expectoration $(p=0.041)$. None patient treated with $600 \mathrm{mg}$ had severe cough after seventh day when a profuse expectoration arose. Therefore, the highest percentage of patients with successful overall response was recorded in this group. Adverse events were mild and mostly attributed to typical disease reactions. French oregano tablets produced a rapid, dependent-dose outcome in patients with common cold, superior to conventional treatment, being also well-tolerated. Cuban Public Registry of Clinical Trials RPCEC00000124.

Keywords: Common cold, upper respiratory tract infections, cough, expectoration, French oregano tablets, placebo. RESUMEN

Las plantas medicinales con propiedades curativas pueden ser útiles en la asistencia médica. El catarro común es una enfermedad muy frecuente, pero su tratamiento no siempre está disponible ni es adecuado. Particularmente, el Orégano francés ha demostrado propiedades expectorantes y antitusivas a nivel no clínico. Se llevó a cabo un ensayo clínico aleatorizado, a doble ciego, controlado con placebo para evaluar si la administración de tabletas de Orégano francés tiene un efecto superior al tratamiento sintomático por la reducción rápida de síntomas del catarro común en pacientes con infecciones del tracto respiratorio superior. Los pacientes recibieron placebo u orégano (300 o $600 \mathrm{mg}$ ), diariamente, durante 15 días, combinado a líquidos abundantes y antipiréticos ante la presencia de fiebre o malestar general. Cada grupo estuvo formado por 30 pacientes. La frecuencia y la intensidad de la tos y la cantidad de expectoración se evaluaron semanalmente. Después de la primera semana de tratamiento, la frecuencia de la tos fue significativamente menor en los pacientes tratados con $600 \mathrm{mg}$ en comparación con los otros grupos $(p=0,003)$. La tos desapareció en 20 pacientes del grupo de dosis mayor. Al mismo tiempo, este grupo tuvo los mejores resultados en cuanto a reducción de la intensidad de la tos $(p=0,046)$ y aumento de la cantidad de expectoración $(p=0,041)$. Ningún paciente tratado con $600 \mathrm{mg}$ presentó tos severa después del séptimo día, momento que sobrevino una expectoración profusa. Por esto, el mayor porcentaje de pacientes con respuesta general satisfactoria se registró en este grupo. Los eventos adversos fueron leves y en su mayoría atribuidos a las reacciones típicas de la enfermedad. Las tabletas de Orégano francés produjeron una respuesta rápida, dependiente de la dosis, en pacientes con catarro común, superior al tratamiento convencional, siendo además bien toleradas. Registro Público Cubano de Ensayos Clínicos RPCEC00000124.

Palabras clave: Catarro común, infecciones del tracto respiratorio superior, tos, expectoración, tabletas de Orégano francés, placebo.

\footnotetext{
${ }^{1}$ Natural and Traditional Medicine Service, Clinical-Surgical Hospital “Dr. Luis Díaz Soto", Havana, Cuba ${ }^{2}$ Clinical Trials Group, Research Direction, Center for Drug Research and Development, Havana, Cuba ${ }^{3}$ Center for Genetic Engineering and Biotechnology, Havana, Cuba
} 


\section{Introduction}

Common cold accounts for half of all acute diseases. ${ }^{1}$ Their incidence has significant geographical and seasonal variations. In winter 6-8 cases per 1000 people per day appear, whereas in summer the daily incidence is reduced until 2-3 cases per 1000 . As average every people present $2-5$ colds per year, increased to 6-8 in young children. ${ }^{2}$

Common cold is a syndrome described as an acute and mild inflammation of the mucous membranes of the upper respiratory tract (especially nose and sinuses). It is characterized by sneezing, runny nose and nasal congestion. Its evolution is about two weeks and rarely is complicated by severe infections, although at present cases up to 30 days of evolution is reported. A red and dripping nose is often characteristic of common cold, but sometimes a mucous nasal discharge, along a protein transudate, could appear conferring the nasal mucosa a crystalline appearance. The yellowish and greenish staining of secretions are due the increased presence of neutrophils, but these are not indicative of bacterial superinfection, since that color should not be a reason to start antibiotic therapy. Another significant respiratory symptom is

\section{Methods}

An exploratory, randomized, double-blind, placebo-controlled clinical study was carried out at the "Dr. Luis Díaz Soto" Hospital, Natural and Traditional Medicine Service, Havana, Cuba. The protocol was approved by the Ethics Committee of this institution and by the Cuban Regulatory Authority, the State Center for the Control of Drugs, Equipment \& Medical Devices (CECMED, reference number: 1486/05.032.09.N). The trial was in compliance with the Helsinki Declaration and its amendments. All patients prior to study enrollment provided their voluntary written informed consent.

\section{Patients}

The study population was constituted by Cuban patients, both sexes, more than 18 years-old, that attend to the clinical site suffering upper respiratory tract infections. The presence of less than 14 days of evolution cough was mandatory accompanied or not of a non-fetid mucous expectoration. Initially, cough can be dry and mild but after 3 or 4 days the patient can expectorate white sputum that can change later to white-yellow or lightly

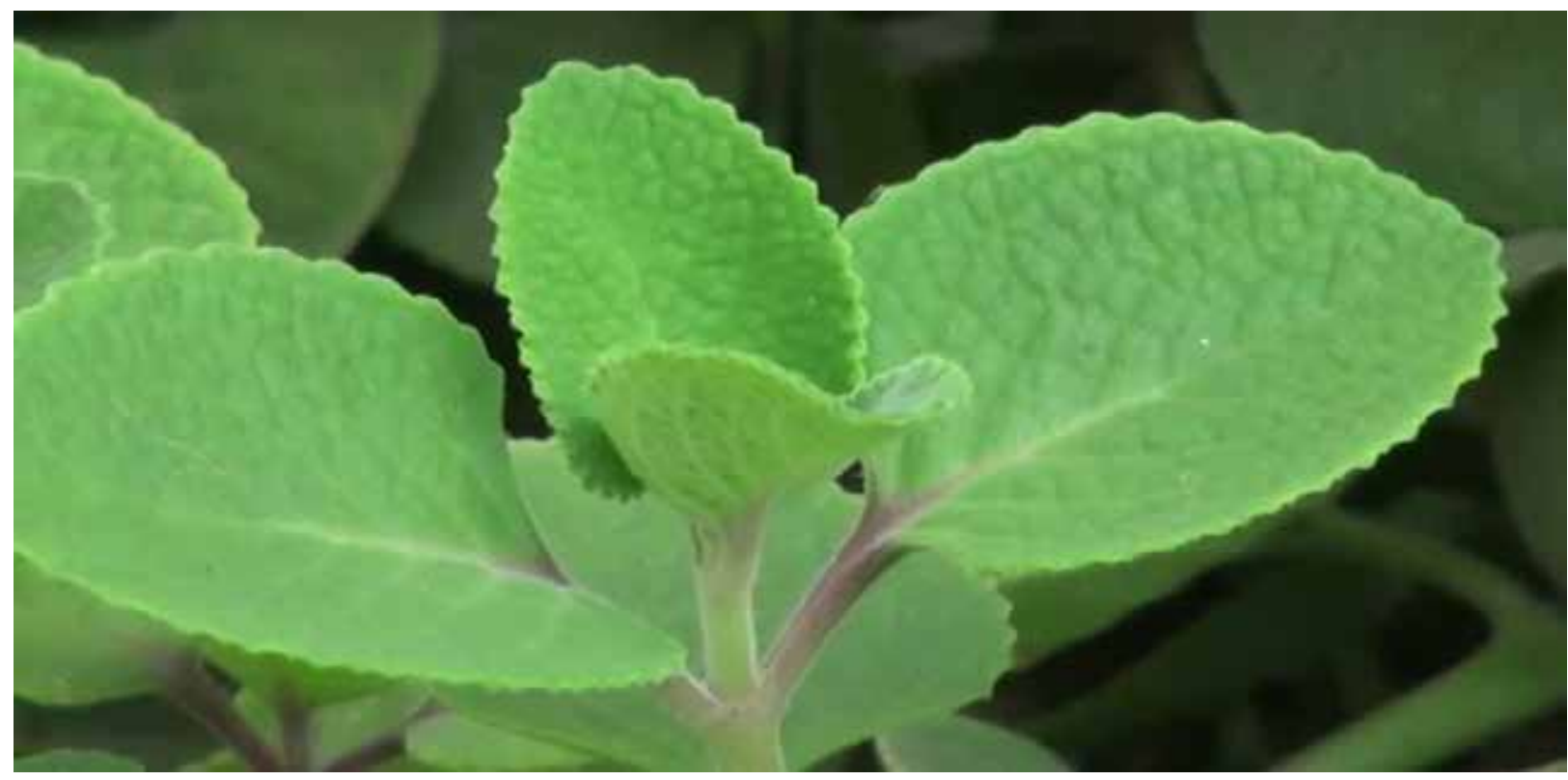

Fig. 1. Plectranthus amboinicus (Lour.) Spreng (French oregano)

cough, initially dry and angry and then may become wet with expectoration. General manifestations also include malaise, anorexia, fever, chills, headache, sore and dry throat, muscle and eye affectations and rhinitis. ${ }^{2}$

Although a number of medications have been shown to have some effect, either on the number or on the severity of common colds, no single agent is considerably effective. ${ }^{3,4}$ The development of natural alternative medical products to improve patient care is well-known. These medicines are widespread used because of its low cost, easy obtain and low rate of adverse reactions. The use of medicinal plants to relieve symptoms of the common cold in acute respiratory diseases is a practice since ancient times. Plectranthus amboinicus (Lour.) Spreng (French oregano) has a recognized ethno-medical use to treat common cold. ${ }^{5}$ The Center for Drug Research and Development (CIDEM, in Spanish), Havana, developed a solid dosage form from the dry extract of French oregano. This natural product exhibited excellent pharmacological and toxicological results in experimentation animals. ${ }^{6-8}$ The present placebo-controlled clinical trial had the aim to evaluate if therapeutic effects of French oregano tablets are similar or better that those from symptomatic treatment in patients with common cold. green, together with a cough enhancement. The diagnosis could also include symptoms such as: nasal congestion, painful or redden throat, fever and respiratory rate $<20 / \mathrm{min}$. Exclusion criteria were: pregnancy or nursing, history or presence at entry of chronic respiratory diseases, lung cancer, antecedents of regular ingestion of steroids and antipsychotics, ingestion of antibiotics or bronchodilators one month before symptoms, cough induced by angiotensin-converting enzyme inhibitors or strange bodies, purulent, serous or bloody sputum, presence of wet stertors at physical examination of the respiratory tract, leukocytes count outside normal range, uncompensated chronic diseases at entry, psychiatric dysfunction and positive HIV test. Patients could withdraw the trial voluntarily, due to disease worsening, occurrence of severe adverse reactions, allergic reaction to studied drug, by appearance of any exclusion criteria or by medical team decision if appropriate.

\section{Treatment}

French oregano tablets of pharmaceutical quality were produced using a technology developed by CIDEM, Havana. The stabilized formulation contains $100 \mathrm{mg}$ of a dry extract from Plectranthus amboinicus (Lour.) Spreng leaves. Each tablet also 
contains as inactive ingredients lactose, cornstarch, polyvinylpyrrolidone $\mathrm{K}-25$, talc for tablets, magnesium stearate and class C 96\% ethylic alcohol.

Three groups of treatment were created using a computer-generated random number list. One group received French oregano (orally) at a daily dose of $300 \mathrm{mg}$, divided into three administrations of $100 \mathrm{mg}$ each, during 15 days. The second group received a daily dose of $600 \mathrm{mg}$, divided into three administrations of $200 \mathrm{mg}$ each. The third group received placebo with the same schedule of treatment. French oregano doses were chosen based on the whole pharmacological data (see Discussion section) also considering that there were no previous findings in humans. All the treatments were administered under outpatient conditions.

To keep masking for the three groups, the same number of tablets was administered. Therefore, for each 100-mg administration one tablet of French oregano and one placebo tablet were used; to give $200 \mathrm{mg}$ two $100 \mathrm{mg}$ tablets were used and for placebo group two placebo tablets were given to these patients. French oregano and placebo tablets looked similar with the same composition regarding excipients.

Random lists were kept at the sponsor's product-preparation department, where flasks containing tablets were labeled. This group was independent from the monitors, investigators or other trial participants. All clinical and laboratory evaluations were done blindly regarding the patient's group allocation. The code was opened only in case of serious adverse events, deaths or at the end of the study, after database closure.

All the patients received the symptomatic treatment established for such cases. This treatment comprised abundant liquid and dipyrone or acetaminophen on the presence of fever or malaise. Other interventions could be only indicated for the management of adverse events, after medical consent. None of them could affect the results because interactions neither direct effects on the tested variables.

\section{Evaluation}

The presence of typical symptoms of common cold, cough and expectoration, was the main clinical outcome in this trial. For cough, frequency and intensity were evaluated, while amount of expectoration was also compared between groups. Measurement of symptoms and physical examination (including vital signs) in the patients were carried out at entry, seven days and at the end of treatment ( 15 days).

The methods used to assess cough and expectoration were designed by experts in the field (Internal Medicine, Pneumology) being approved by the ethics committee and scientific council of the clinical site. An adaptation of the Modified Borg Scale was applied. ${ }^{9}$ Its use is similar to the visual analogue scale, but helping the patient through some key phrases at certain points of the scales. These are categorical scales where each phrase that describes cough and expectoration is assigned by a score. Patients are requested to assign a number from 0 (no cough, no expectoration) to the maximum number of events, according to the phrase that best describes the current state thereof.

To evaluate cough frequency within 24 hours was employed the following score: (0): no cough; (1): 1-4 times; (2): 5-10 times; (3): 11-15 times; (4): $>15$ times. Cough intensity during the same period was considered as (mild): $<5$ coughing, with expectoration; (moderate): 5-10 coughing, with nausea, vomiting, headache, chest pain and tachycardia and (severe): $>10$ coughing that could or not prevent patient's vital activities such as eating and sleeping. On the other hand, amount of expectoration was classified as null expectoration (no events / 24h), mild expectoration (1-5 times / 24h) and profuse expectoration ( $>5$ times / 24h).

Additionally, treatments were classified as successful, proper or unsatisfactory at the 7 th and 15th days of treatment. Patients with successful response were those with a $90 \%$ both cough re- duction and expectoration increase. A proper response occurred when cough decrease and expectoration increase were between 70 and $90 \%$. Patients that no changed their clinical condition, presented signs of acute respiratory infection or increased disease symptoms had unsatisfactory response.

Safety and tolerability were monitored during the study through registration of adverse events. Events were severe if produce patient's death, threatens patient's life, requires or prolongs hospitalization or produce a significant or persistent disability. The medical terminology for adverse events and their intensity classification (in 5 grades) was applied according to the Common Terminology Criteria for Adverse Events. ${ }^{10}$ The causal relationship was classified as remote (doubtful), possible, probable or very probable (definitive). ${ }^{11}$

Blood samples were taken for routine hematological and biochemical determinations before and after treatment. Hematological counts (hemoglobin, hematocrit, leukocytes) and blood chemistry (glycemia, cholesterol, creatinine, alkaline phosphatase, total bilirubin and triglycerides) were done according to usual clinical laboratory procedures, using advanced automated analyzers (Elimat, Hitachi, Tokyo, Japan; Inlab 158, CPM, Milan, Italy).

\section{Statistics}

Sample size was calculated using the equation $\mathrm{n}=[\mathrm{Za}+$ Z $\beta$ ) $\sigma / \delta]^{2}$ assuming 0.05 and 0.85 for type I and II errors. The " 2 N" Program was used for this purpose. ${ }^{12}$ A $10 \%$ excess was considered to compensate withdrawals. This yielded a value of 90 patients (30 per group) for this trial.

Data were double entered and validated and then imported into SPSS for Windows (version 15.0, IBM Analytics 2006, Armonk, North Castle, NY, USA) for further analysis. Categorical variables were given as absolute values and percentages. Continuous variables were expressed as mean \pm standard deviation (SD) and minimum and maximum values (range). With these variables, analyses of normality (Shapiro Wilk's test) and homogeneity of variance (Levene's test) were carried out. Groups were compared for the primary endpoints at the beginning and at the 7 th and 15th days of treatment using contingency table chi-square test with the aim to establish dependency relationships between evaluated symptoms (frequency and intensity of cough, amount of expectoration) and treatment received. Vital signs and clinical laboratory data were treated using paired analysis. Significance level chosen was 0.05 .

\section{RESULTS}

One-hundred patients were recruited from March 2011 to July 2012 to select finally those 90 patients that were randomly distributed to each group ( 30 per each one). The other ten patients did not fulfill with the selection criteria. All the patients completed the 15 days of treatment.

Demographic and baseline characteristics at entry of the included patients are shown in Table 1. Groups were similar regarding each characteristic. Globally, 70\% of patients were women with a mean age around 50 years (range: 19-84 yrs). Non-white skin color prevailed (60\%). They weighed 40 to $105 \mathrm{Kg}$ and were 148 to $198 \mathrm{~cm}$ tall. Patients ranged $2-10$ days suffering cough (mean: 6 days) into each group. History of allergy was something inferior to half of patients whereas risk exposure (mostly dust) was not very frequent. Regarding habit toxics, consumption of coffee was common ( $>75 \%$ of patients) and patients included in French oregano groups were slightly more smokers.

Before treatment groups were also similar regarding cough and expectoration as observed in Figure 1. No differences were detected for the frequency and intensity of cough neither amount of expectoration; therefore, the hypostasis of a dependency be- 
Table 1. Demographic and baseline characteristics of the patients involved in the clinical trial with French oregano (300 or $600 \mathrm{mg} /$ day) and placebo during 15 days.

\begin{tabular}{|c|c|c|c|c|}
\hline \multicolumn{2}{|c|}{ Characteristic } & Group 1 (300 mg) & Group 2 (600 mg) & Group 3 (placebo) \\
\hline & & $\mathrm{N}=30$ & $\mathrm{~N}=30$ & $\mathrm{~N}=30$ \\
\hline \multirow[t]{2}{*}{ Skin color } & White & $10(33.3 \%)$ & $15(50.0 \%)$ & $11(36.7 \%)$ \\
\hline & Non-whlite & $20(66.7 \%)$ & $15(50.0 \%)$ & $19(63.3 \%)$ \\
\hline \multicolumn{2}{|c|}{ Women } & $15(50.0 \%)$ & $24(80.0 \%)$ & $24(80.0 \%)$ \\
\hline \multicolumn{2}{|c|}{ Age (years) } & $50 \pm 18(19-75)$ & $52 \pm 19(19-84)$ & $52 \pm 16(20-84)$ \\
\hline \multicolumn{2}{|c|}{ Weight $(\mathrm{Kg})$} & $64 \pm 16(40-96)$ & $72 \pm 13(48-97)$ & $68 \pm 15(42-105)$ \\
\hline \multicolumn{2}{|c|}{ Height (cm) } & $160 \pm 8(148-180)$ & $165 \pm 9(148-180)$ & $161 \pm 12(148-198)$ \\
\hline \multicolumn{2}{|c|}{ Days with cough } & $6 \pm 2(2-10)$ & $6 \pm 2(2-10)$ & $6 \pm 2(2-10)$ \\
\hline \multicolumn{2}{|c|}{ History of allergy } & $13(43.3 \%)$ & $13(43.3 \%)$ & $15(50.0 \%)$ \\
\hline \multicolumn{2}{|c|}{$\begin{array}{c}\text { Risk exposure (gases, dust, } \\
\text { others) }\end{array}$} & $5(16.7 \%)$ & $5(16.7 \%)$ & $4(13.3 \%)$ \\
\hline \multirow[t]{3}{*}{ Toxic habits } & Smoke & $10(33.3 \%)$ & $7(23.3 \%)$ & $4(13.3 \%)$ \\
\hline & Alcohol & $8(26.7 \%)$ & $8(26.7 \%)$ & $6(20.0 \%)$ \\
\hline & Coffee & $25(83.3 \%)$ & $22(73.3 \%)$ & $23(76.7 \%)$ \\
\hline
\end{tabular}

Data are reported as number of patients $(\%)$ or mean \pm standard deviation (range).

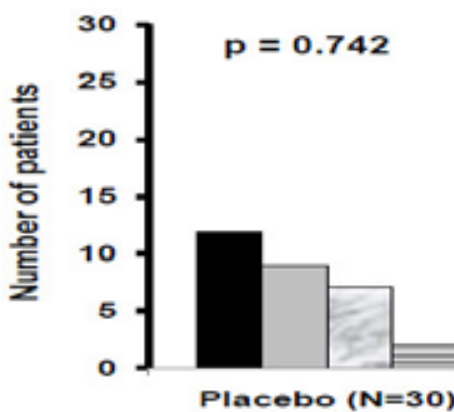

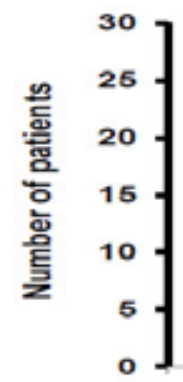

$p=0.983$

(2)

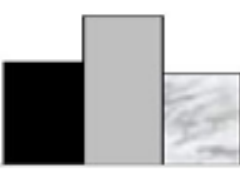

Placebo $(\mathbf{N}=30)$ $p=0.362$

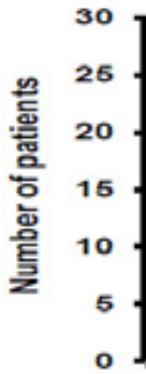

A

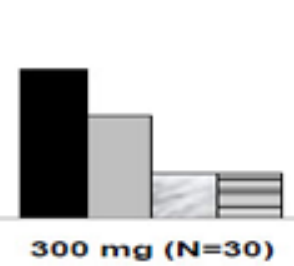

B

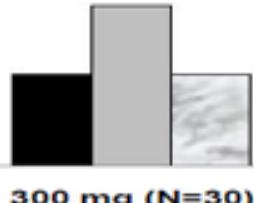

C
- 1-4 times

ㅁ 5-10 times

ㅁ 11-15 times

ㅁ $>15$ times

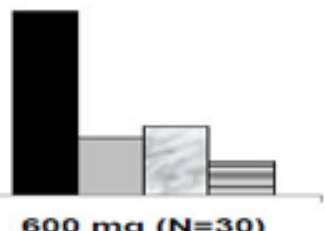

$600 \mathrm{mg}(\mathrm{N}=30)$

- Mild

口 Moderate

口 severe

Figure 1

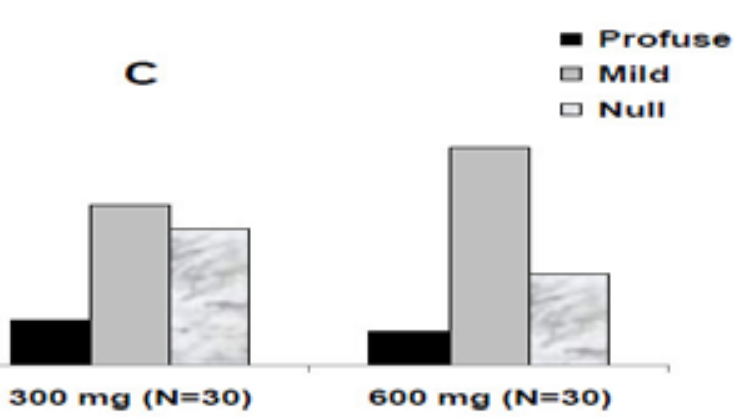

Fig. 1. Symptomatic characterization before treatment with French oregano (300 or $600 \mathrm{mg} / \mathrm{d}$ ) or placebo..

Legend: Data correspond to patients with common cold distributed into each category for each group of treatment, according to the adaptation of the Modified Borg Scale. (A): cough frequency; (B): cough intensity; (C): amount of expectoration. The contingency table chi-square test was used to establish dependency between variables and groups ( $p>0.05$ in all cases). For a better visualization, all the scales were put at the same level. 
tween these variables and treatment was no observed. The prevalence of an initial moderate cough and mild expectoration outstand in the three groups. A strong relationship of dependency between studied variables and the treatment received was obtained after seven days of treatment (Fig. 2). Daily administration of $600 \mathrm{mg}$ of French oregano influenced significantly in the evolution of cough and expectoration. No cough was obtained in two thirds of patients from this group which impacted in the intensity since almost all patients were grouped as mild cough. Contrary patients treated with placebo or $300 \mathrm{mg}$ of the same product achieved mostly 1-4 events in 24 hours and no cough was only reported in 6-7 patients. At this time, severe cough was only reported in these two groups. rior to the other groups, which was only $27 \%$ and $20 \%$ for $300 \mathrm{mg}$ and placebo groups, respectively (Table 2). In the group that received highest dose, patients with successful and proper response raised to $86.7 \%$, only seven patients $(23.3 \%)$ did not respond to this treatment. Non-responders (unsatisfactory) in the placebo group were $63.3 \%$, being $50 \%$ in the group treated with the lower dose of the studied drug.

After 15 days of treatment only a minimum of patients had cough and expectoration. No influence of toxic habits or any other demographic or baseline characteristic on outcome variables was detected (data not shown).

Only six patients presented adverse events during the treatment (Table 3). Only one patient, from $300 \mathrm{mg}$ group, registered
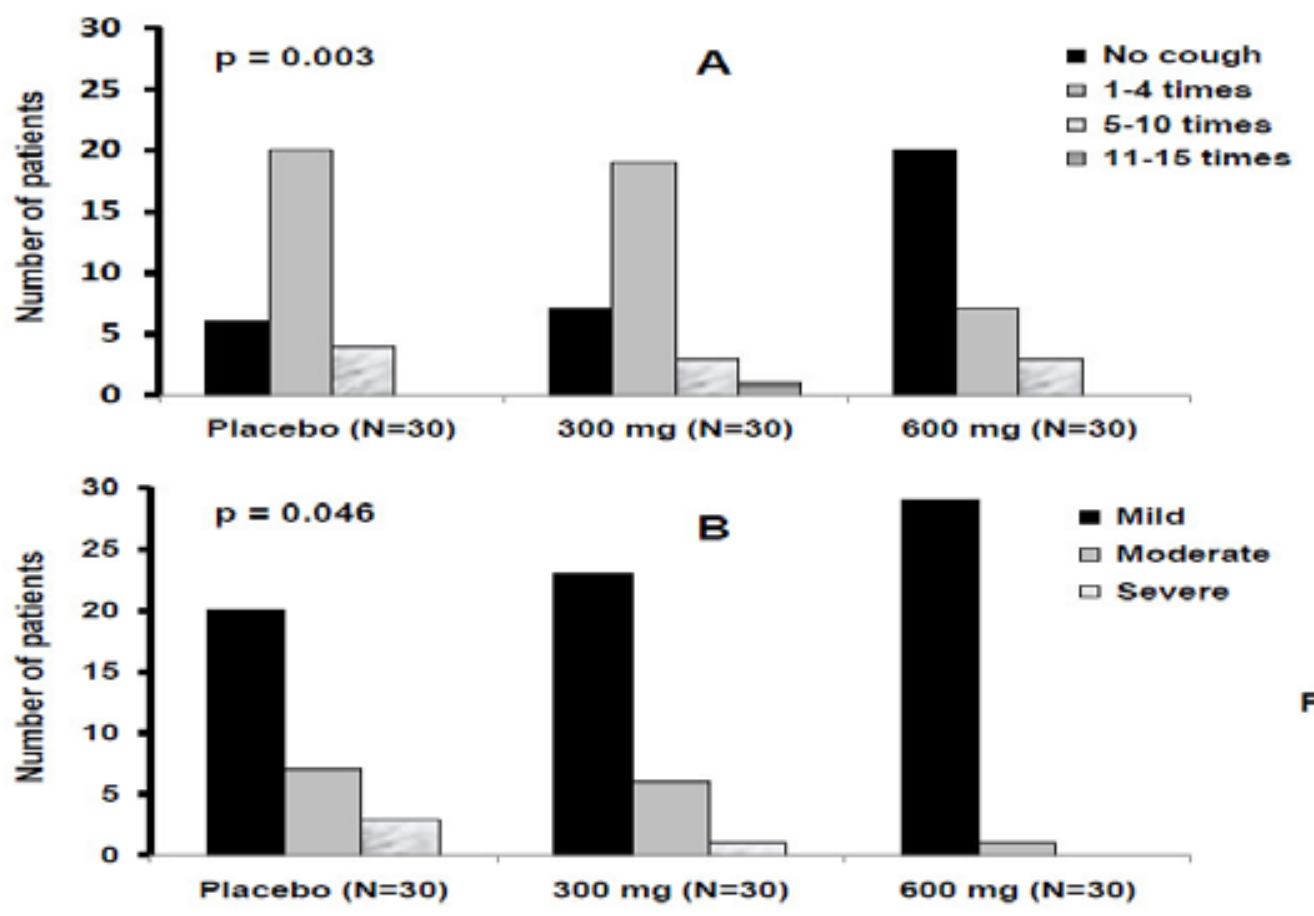

Figure 2

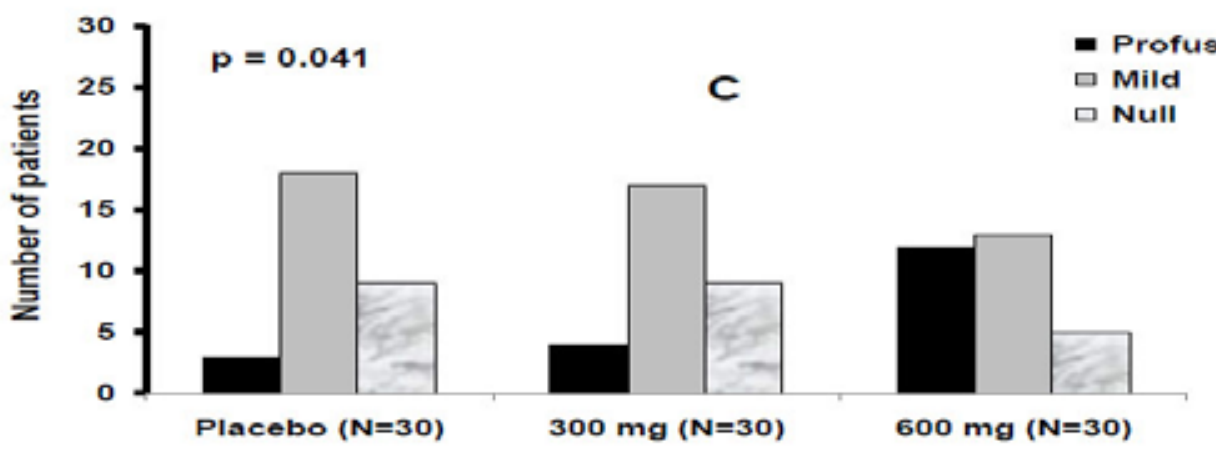

Fig. 2. Symptomatic characterization after seven days of treatment with French oregano ( 300 or $600 \mathrm{mg} / \mathrm{d}$ ) or placebo.

Legend: Data correspond to patients with common cold distributed into each category for each group of treatment, according to the adaptation of the Modified Borg Scale. (A): cough frequency; (B): cough intensity; (C): amount of expectoration. The contingency table chi-square test was used to establish dependency between variables and treatments ( $\mathrm{p}<0.05$ in all cases). For a better visualization, all the scales were put at the same level. All the patients received the conventional symptomatic treatment.

At the seventh day expectoration was profuse in $12 / 30$ patients treated with the highest dose, appearing in that form only in three and four patients from placebo and $300 \mathrm{mg}$ groups, respectively. Even nine cases continued with null expectoration in these last groups (Fig. 2). Some patients from $600 \mathrm{mg}$ group passed from initial severe intensity to no cough together with a change from null to profuse expectoration.

Consistent with the above described results, after seven days of treatment the half of patients treated daily with $600 \mathrm{mg}$ of French oregano had overall successful response, markedly supe- more than one event (pharyngeal itching, sore throat). Most of the events occurred in patients treated with French oregano but these were mostly typical respiratory symptoms classified as remotely caused by treatment.

All the events were classified as non-severe, mild intensity, resolved without therapeutic intervention between 12 and 72 hours after their appearance around eight hours after administration. Significant differences or variations in vital signs or clinical laboratory tests were not detected and mean values kept within normal ranges. 
Table 2. Overall response after seven days of treatment with French oregano (300 or 600 $\mathrm{mg} / \mathrm{d})$ or placebo.

\begin{tabular}{|cccc|}
\hline Response & Group 1 (300 mg) & Group 2 (600 mg) & Group 3 (placebo) \\
& $\mathrm{N}=30$ & $\mathrm{~N}=30$ & $\mathrm{~N}=30$ \\
\hline Successful & $8(26.7 \%)$ & $15(50.0 \%)$ & $6(20.0 \%)$ \\
\hline Proper & $7(23.3 \%)$ & $8(26.7 \%)$ & $5(16.7 \%)$ \\
\hline Unsatisfactory & $15(50.0 \%)$ & $7(23.3 \%)$ & $19(63.3 \%)$ \\
\hline
\end{tabular}

Data are reported as number of patients (\%).

Table 3. List of adverse events recorded during treatment.

\begin{tabular}{|cclcccccc|}
$\begin{array}{c}\text { Patient's } \\
\text { code }\end{array}$ & Group & \multicolumn{1}{c}{ Adverse event } & Severity & Intensity & Causality & Conduct & Result \\
\hline LFLS-12 & $600 \mathrm{mg}$ & Epigastric burning & NS & Mild & Remote & None & Resolved \\
\hline MPP-13 & $300 \mathrm{mg}$ & Sore throat & NS & Mild & Possible & None & Resolved \\
\hline YFT-63 & Placebo & Dry mouth & NS & Mild & Possible & None & Resolved \\
\hline LLIN-74 & $300 \mathrm{mg}$ & $\begin{array}{l}\text { Labial mucous } \\
\text { itching }\end{array}$ & NS & Mild & Remote & None & Resolved \\
\hline MGR-77 & $300 \mathrm{mg}$ & Pharyngeal itching & NS & Mild & Remote & None & Resolved \\
\hline MGR-77 & $300 \mathrm{mg}$ & Sore throat & NS & Mild & Remote & None & Resolved \\
\hline EGC-79 & $600 \mathrm{mg}$ & Suffocation & NS & Moderate & Remote & None & Resolved \\
\hline
\end{tabular}

NS: Non-severe

\section{DISCUSSION}

In this study, French oregano at a daily dose of $600 \mathrm{mg}$, divided in $200 \mathrm{mg}$ every eight hours, proved to be a rapid, effective and safe treatment in patients with common cold, reducing cough and increasing expectoration after only seven days of treatment. The increment in the amount of expectoration means a higher volume of bronchial secretions and stimulation of the mechanisms of elimination, which helps the improvement of clinical status of the patients. In that sense, patients that no longer had a cough maintained expectoration process. At the same time outcomes with daily $300 \mathrm{mg}$ of the same natural product and placebo were significantly inferior and no different among them. Therefore, tablets of French oregano showed a better therapeutic effect (reversion of the initial symptoms) than symptomatic treatment, considering $600 \mathrm{mg}$ every 24 hours the effective dose.

These results demonstrate that the dry extract obtained from aqueous extracts of Plectranthus amboinicus (Lour.) Spreng leaves could act on the respiratory tract by modifying secretion and bronchial motility, reducing in turn cough intensity. The relieve of cough is produced due to the presence of a thick and irritating secretion that in concert with the mucus secreted, naturally demulcent, both protect the inflamed mucosa and reduce cough reflex. ${ }^{13}$ So expectorants behave as soothing cough when it is unproductive.
Decoctions from French oregano leaves are used in traditional medicine for the treatment of common cold based in their bronchodilator and expectorant activities. ${ }^{14}$ The current findings corroborate those achieved in previous preclinical studies with this extract, ${ }^{7,15}$ allowing classifies it within expectorants and antitussive substances.

The administration of aqueous extract and of fluid extract as well as the syrups produced from French oregano extracts resulted in significant increase of red phenol concentration in the tracheobronchial secretion of mice. In turn, the acute administration of $100 \mathrm{mg}$ tablets had the same expectorant effect as bromhexine and salbutamol. ${ }^{7}$ The product had antitussive effect in the experimental model of aerosol ammonia in guinea pigs. ${ }^{15}$ Toxicogenetic and subcrhonic studies showed that the plant is not toxic. ${ }^{6,8}$

On the other hand, French oregano tablets led to immediate contraction of the smooth musculature. French oregano showed a manifest antimuscarinic effect after induction with acetylcholine, deducing both agonist and antagonist effect of cholinergic transmission. ${ }^{16}$ Moreover, the same authors found that this medication inhibited passive cutaneous anaphylaxis and increased the contractile effect of adrenaline on the vas deferens in rats and showed in vitro antihistamine effect on gut $\mathrm{H} 1$ receptors. ${ }^{17}$

Clinical trials using French oregano contained in solid dosage forms are not easily found in the literature. In the current 
study, adverse events reported were mild, typical of patients with common cold, consequence of a viral infection, usually without fever and manifested by inflammation of the upper respiratory tract, with a viral incubation period lasts between 24 and 72 hours. At this time appear nasal nuisances, including pharyngeal affectations with itching and sore throat. ${ }^{2}$

Considering the problem that this disease does not have a gold standard treatment, a safe and physiologically effective new medication of natural origin could improve patient care, with a consequent improvement in their quality of life.

\section{Conclusions}

French oregano tablets at the better dosing schedule could be a reasonable alternative to other symptomatic treatments in patients with common cold. Further, more extensive, controlled clinical trials are encouraged to confirm the rapid clinical response obtained with this natural product.

\section{Acknowledgments}

The authors wish to thank Terasa Pujol, Maricela Cabezas, Azalia Díaz, Damaris Herrera, Denise Delgado, Lien Laguna, Bárbara Palacio, Carlos Mederos, Yenisel Cárdenas, Madelaine Castro, Isel García, Maria de las Nieves, Nilda Herrera and Ana de Armas for their assistance in the clinical work, and Osiris Blanco, Maylín Díaz, Marilyn López and Beatriz Elizagaray for their participation in the trial supporting. The study was also supported by the national project I13010: Plectranthus amboinicus (Lour.) Spreng (French oregano) formulations for sanitary registration. The authors received French oregano tablets free from CIDEM,

\section{Competing interests}

Authors DJR, TFC and IGG are employees of the Center for Drug Research and Development (CIDEM), Havana, Cuba, where French oregano formulation is produced. The rest of the authors have no competing interests at all. The Ministry of Public Health of Cuba supported the clinical trial (hospital facilities and general medical care of the patients).

\section{Authors' contributions}

YARC was the main investigator. DJR, JERC and TFC conceived, designed and coordinated the study, data processing and analyzed the results; DJR also participated in the manuscript writing. MGS, MCLA and JPR took care of patient recruitment, management, clinical examinations, and follow-up. ADTI contributed as data processor and statistician. IGG analyzed the results and wrote the manuscript draft. All authors read and approved the final manuscript

\section{Referencias bibliográficas}

1.Muñoz FM, Galasso GJ, Gwaltney JM Jr, Hayden FG, Murphy B, Webster R, et al. Current research on influenza and other respiratory viruses: II International Symposium. Antiviral Res 2000; 46(2):91124.

2.The Common Cold. Section B. Upper Respiratory Tract Infections. Part II Major Clinical Syndromes. In Mandell, Douglas, and Bennett's Principles and Practice of Infectious Diseases, 8th Edition. Philadelphia: Saunders; 2015.

3. Heikkinen T, Järvinen A. The common cold. Lancet 2003; 361(9351):51-59. DOI: 10.1016/S0140-6736(03)12162-9.

4.Passioti M, Maggina P, Megremis S, Papadopoulos NG. The common cold: potential for future prevention or cure. Curr Allergy Asthma Rep 2014; 14(2):413. DOI: 10.1007/s11882-013-0413-5.

5.Arumugam G, Swamy MK, Sinniah UR. Plectranthus amboinicus (Lour.) Spreng: Botanical, Phytochemical, Pharmacological and Nutritional Significance. Molecules 2016; 21(4):369. DOI: 10.3390/ molecules21040369.

6.Vizoso-Parra A, Ramos-Ruiz A, Edreira-Armenteros A, Betancourt-Badell J, Décalo-Michelena M. Plectranthus amboinicus (Lour.) Spreng (orégano francés). Estudio toxicogenético de un extracto fluido y del aceite esencial. Rev Cubana Plant Med 1999; 4(2). URL: http://scielo.sld.cu/scielo.php?script=sci_arttext\&pid=S1028-47961999000200005

7.Bárzaga-Fernández P, Tillán-Capó J, Marrero-Cofiño G, Carrillo-Domínguez C, Bellma-Menéndez A, Montero-Alarcón C. Expectorant activity of formulations from Plectrantus amboinicus (Lour) Spreng (French oregano). Rev Cubana Plant Med 2006; 14(2). URL: http://scielo.sld.cu/scielo.php?script=sci_arttext\&pid=S1028-47962009000200008

8.Tillán-Capó J, Bueno-Pavón V, Menéndez-Castillo R, Carrillo-Domínguez C, Ortiz-Infante M. Subchronic toxicology of the aqueous extract of Plectranthus amboinicus (Lour.) Spreng. Rev Cubana Plant Med 2008; 3(1). URL: http://scielo.sld.cu/scielo. php?script=sci_arttext\&pid=S1028-47962008000100004

9. Rating of perceived exertion: Borg scales. Source: www.heartonline. org.au/resources. Reviewed 11/2014.

10. Common Terminology Criteria for Adverse Events (CTCAE), Version 4.0, Published: May 28, 2009 (v4.03: June 14, 2010), DCTD, NCI, NIH, DHHS. URL: http://ctep.cancer.govCigna E, Tarallo M, Maruccia M, Sorvillo V, Pollastrini A, Scuderi N. Basal Cell Carcinoma: 10 Years of Experience. J. Skin Cancer. 2011 [citado 17 de junio de 2014]. Disponible en: http://dx.doi.org/10.1155/2011/476362.

11. Naranjo CA, Shear NH, Busto U. Adverse drug reactions. In: Kalant H, Roschlau WHE, editors. Principles of Medical Pharmacology, 6th ed. New York: Oxford University Press 1998, pp. 791-800.

12. "2N" Program for Design of Clinical Trials, Program for Calculation of Sample Size for a Clinical or Experimental Study, PhD Martín HauerJensen, University of Arkansas for Medical Sciences. Rosner B. Fundamentals of biostatistics. 3rd ed. Boston: PWS Kent Publishing Company; 1990.

13. Farreras Rozman. Tratado de Medicina interna. Enfermedades respiratorias agudas, 14 ed., Barcelona 2004. pp. 809-834.

14. Acosta L, Rodríguez C. Plantas Medicinales. Base para su producción sostenible. Ed. Agroinf. MINAG. La Habana. 2006. p. 134-135.

15. Núñez Y, Tillán J, Carrillo C, Menéndez R, Pavón V, León R. Evaluación de la actividad antitusiva del Plectranthus amboinicus [Lour] Spreng tabletas $100 \mathrm{mg}$. Informe técnico. CIDEM. La Habana, 2001.

16. Núñez-Figueredo Y, Tillán-Capó JI, Carrillo-Domínguez C, Montero-Alarcón C, Menéndez-Castillo R, Diego León R. Activity of Plectranthus amboinicus (Lous.) Spreng $100 \mathrm{mg}$ tablets on the intestinal smooth musculature. Rev Cubana Plant Med 2006; 11(3-4). URL: http://scielo.sld.cu/scielo.php?script=sci_arttext\&pid=S1028-47962006000300003

17. Núñez-Figueredo Y, Tillán-Capó JI, Carrillo-Domínguez C, Menéndez-Castillo R, Diego León R. Effect of Plectranthus amboinicus (Lour.) Spreng tablets on the passive cutaneous anaphylaxis, histaminergic and adrenergic transmission. Rev Cubana Plant Med 2006; 11(3-4). URL: http://www.bvs.sld.cu/revistas/pla/vol11_3-4_06/ pla05306.htm

Recibido: 20 de octubre de 2016. Aprobado: 3 de diciembre de 2016. 